\title{
岩手 縣の火災氣象地理
}

藏重・紊

1. 序 論 火梁の季渻変化には地域性があ 万事が知られている。例そば年周で火桨问数の最 大の川在地域的に㖞げる上次の如くである。

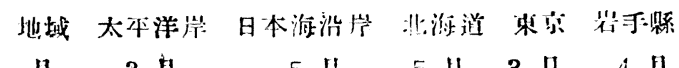
月 3 为 5 川 5 月 3 月 4 月

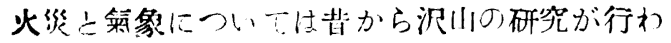

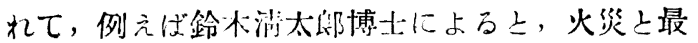

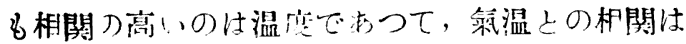

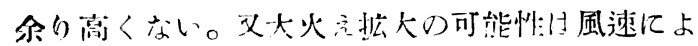

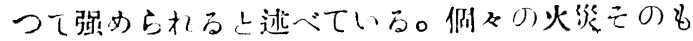
のの原因は人第的なものであるにせよ, 広区域に

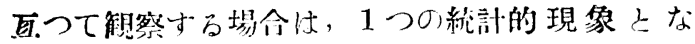
り，之れた支配する自然現像的要秦が引き出され て來ら多の上侤えら机万。卜裴の如く, 火災の季

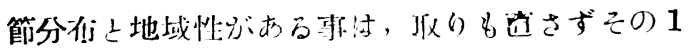

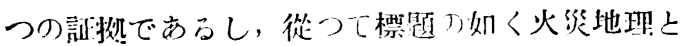
云うものが必然的に考えられてよい上思う。

次に岩手跞下の月别火㷋緿計裴在揭げる，

表にけ水沢の温度在俳記した。表に見る柡に火

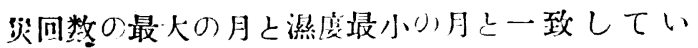
て, 全体として火范回数は潪度上逆の相関在示し いろc唯12月に対しては例外が是ら机万。瀿度之问 数の相閔係数は一 0.855 で可成大きい任在示す。

2. 燒失面積, 燒失面皘引數 次に月别の燒失面 䄸を調へて見る。

表から分る如く，燒火面稳は 4 月が最大であ

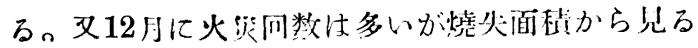
亡4月の㵖・/3である。この事から12月の火啖け小規 模なものが多いと推测される。そして，燒头面秥 を支配士る因子上火织问数支支配与る网子上に差

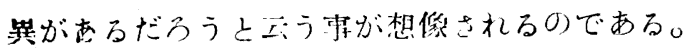

第1 表 苔手綦下川别火災統計表 (大正 3-昭利 3)

$$
\text { 月 }
$$

火災回数（回 1 月）

$\begin{array}{lllll}1 & 2 & 3 & 4\end{array}$

瀑 度 (水 沢)\%

第 2 表 乃別焼火面稍 (百渄單位)

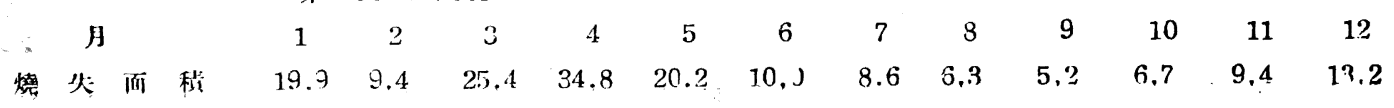

以下の釷論はこの焼失面積を対像とすろ。その 前に注意寸万事は人家が稠泌な程燒失面程は大き

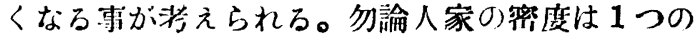
地理的要件け1つではあるが,ここではこの漛な 人爲的のものt考引い下自然的要因一要するに氣 像的或いは氣候的要因一を抽出する事を杼めてみ る。さて手詐にある統計は岩手㧛下の整察署管內

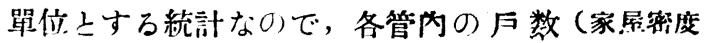
のカがより通切だがここでは顽の數を指標に收つたつ 之燒失面程を対比して見る。その結果は第 1 図の 如くなり，両者の闑係は指数万数的關係にあつ て，戶数が悡すにつれて燒头面皘は慜增す万事が 分万。耐者の, 是係壮

$$
\begin{aligned}
& Y=2.5 e^{299 x} \quad Y \text { : 焼火面积 }(\text { 單位 }=10 C \text { 报 }) \\
& \mathrm{X} \text { : 戶數（單位 }=10 \text { 局） }
\end{aligned}
$$

である。そこで実驗式から求めた燒失面積で実際

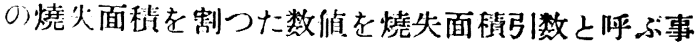
にする。この引数老用いる事によつて戶数の大小

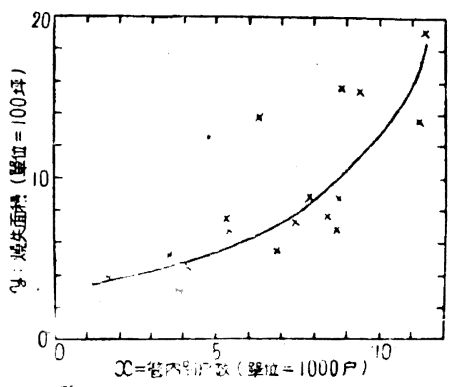

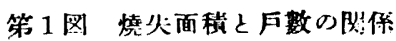


によろ要因は除かれた事になり紆粹に自然的なも のだけが线ると考えられる。次表に郡氿别 0 ，焙失 面能と引数とを示す。

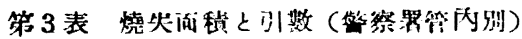

\begin{tabular}{|c|c|c|c|c|}
\hline & & & 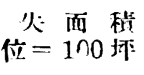 & 引 數 \\
\hline 盛 & & $M_{i}$ & 7.6 & 0.35 \\
\hline 沼 & 宮 & 內 & 7.4 & 1.25 \\
\hline 日 & & 詰 & $\cdot 5.3$ & 0.70 \\
\hline 花 & & 兊 & 7.6 & 0.79 \\
\hline 黑 & 沢 & 尻 & 8.7 & 0.86 \\
\hline 川 & & 尼 & 3.7 & 1.16 \\
\hline 水 & & 沢 & 19.1 & 1.20 \\
\hline 岩 & 谷 & 堂. & 7.2 & 0.86 \\
\hline- & & 閶 & 6.7 & 0.64 \\
\hline 千 & & 厩 & 13.6 & 0.88 \\
\hline 盛 & & 岡 & 15.1 & 1.43 \\
\hline 遠 & & 野 & 6.7 & 1.12 \\
\hline 鉒 & & 石 & 6.6 & 1.62 \\
\hline 宮 & & 古 & 15.5 & 1.37 \\
\hline 岩 & & 泉 & 5.1 & 1.12 \\
\hline 久 & & 慈 & 13.9 & 1.99 \\
\hline 蛏 & & * & 4.5 & 0.96 \\
\hline 福 & & 䎟 & 8.7 & 0.91 \\
\hline
\end{tabular}

この引数の分布地図を描く之第 2 困の如くな る。即ち北上河谷で忧が值かさく, 海岸地方で大 きい。特に, 釜石附近と夥北部で, 久慈・岩手川辺 りを結ぶ一带が値が大きいのが著しい事項である。

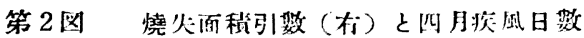
(店)上小分布

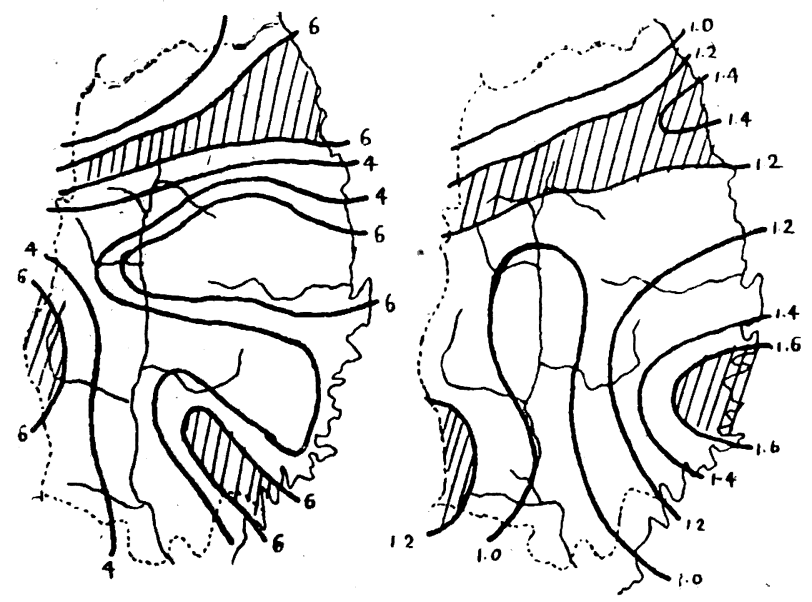

3. 燒失面積引數と氮象要素との相關 燒失面 積引数之氣象要素との相閔䋆数を求わた結果を次 表に示守。

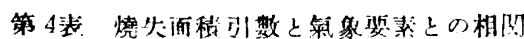
本均㵊低 4 Hの疾風 4 川尔均敏㴓

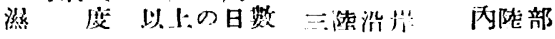

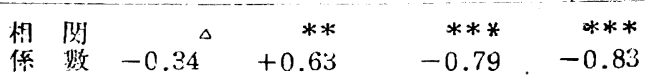

表の中で是印 3 倜を附した佔は統計的檢定で概

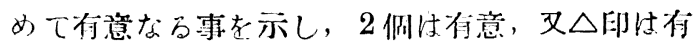
意で無い事在示す。

表からみる椂に最低温度との相関は低くて相関

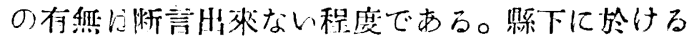
本均最但温度の分在老みると，三陸沿崖の方に高 く內陸部に小さと，最も低心地域代夥の北无部に 当つている。北上河谷南部系割合温度が高く，こ れは，金菲附近から海風の流入がある䈆であ る。この分住は燒失面积引数が激岸に高いと云う 串契之刘比しても温度との相関は小さい事がうな ずける。

次に次風以上の日数之の相関付有意であつて， 風の强い所程燒少面積が大きい傾向がある。そこ

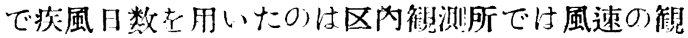

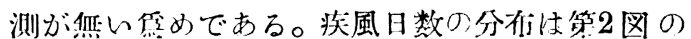
右に示したが，図か巨焼失面積引数の分推とかな り上く似ている事が分るであ万う。

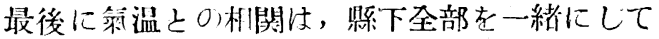
考えると，相関は小さいが，三陸沿岸部之內陸部之 は, 策温対燒失面皘引数のグラプ上で明が别 の）遖線に涞らので:雨地域に分離して相関係数を

求める上表の如く，晸めて有意な関䋆がみら れ温度の低い地方程燒失面䅡が大きいと云う 結紧を得る。

4. 三陸沿岸と內陸部との相違 前節の如 く三佺沿岸と冈陸部との間に村違があるとす れば，その原因は何であるかを統計的に推定 してみた。檢定の結果は次の表に示す。

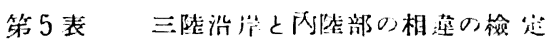

\begin{tabular}{|c|c|c|c|c|}
\hline & 人耐稆 & 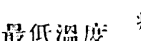 & 状夙以上 & 不均 \\
\hline & & & 數 & 策潈 \\
\hline 內陵部 & $\begin{array}{c}0.87 \\
(0.06)\end{array}$ & $\begin{array}{c}36 \\
(1.71) * *\end{array}$ & $\begin{array}{r}2.2 \\
(0.97)\end{array}$ & $\begin{array}{c}8.1 \\
(0.89)\end{array}$ \\
\hline 三陸沿挩 & $\begin{array}{c}1.57 \\
(0.18)\end{array}$ & $\begin{array}{c}33 \\
(11)\end{array}$ & $\begin{array}{r}5.4 \\
(0.49)\end{array}$ & $\left(\begin{array}{c}8.5 \\
(0.60)\end{array}\right.$ \\
\hline$F_{1}$ & $15.4 * *$ & $2.49 \Delta$ & $13.6 * *$ & $1.89 \Delta$ \\
\hline $\mathrm{F}_{0}(5 \%)$ & $\begin{array}{l}4.49 \\
8.53\end{array}$ & $\begin{array}{l}4.54 \\
8.68\end{array}$ & $\begin{array}{l}4.67 \\
9.07\end{array}$ & $\begin{array}{l}4.54 \\
8.68\end{array}$ \\
\hline 変 換 & & $\log (33-$ & 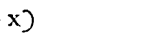 & \\
\hline
\end{tabular}

両地域の各速の本均值吉探つて両者が同-

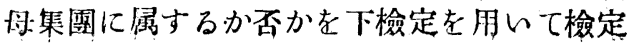




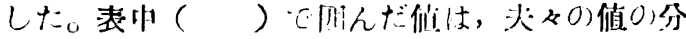

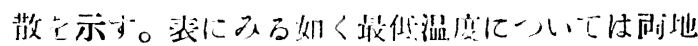

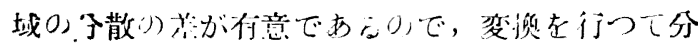
散老闹じにして此紧している。

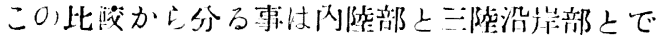

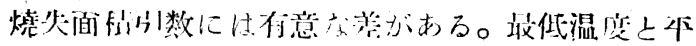

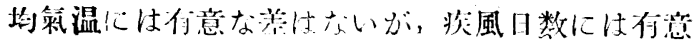

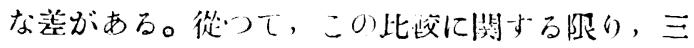

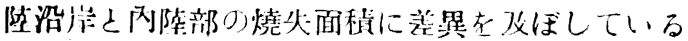
氣象的网子・时風速であると判忻される。

你地域别门最多火㷋発生月在表示寸万次の如 くなる。

管內名。最多火災月

\begin{tabular}{|c|c|c|c|c|c|}
\hline 盛 & 閵 & 4,2 & 千 & 既 & 1 \\
\hline 冬，宮 & 历 & 2,12 & \multicolumn{2}{|c|}{ 盛 } & 4 \\
\hline 日 & 詰 & 2,1 & 喷 & 野 & 3 \\
\hline 花 & 怣 & 4 & 釟. & 不 & 5,12 \\
\hline 黑沢 & 尼 & 4 & 5 & 古 & 1,4 \\
\hline 川 & 尼 & - & 楽: & 杲 & 4 \\
\hline 水 & 沢 & 4 & 久 & 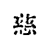 & 4 \\
\hline 岩 谷 & 堂 & 5 & 㳗 & * & 5 \\
\hline$\ldots$ & B & 2,5 & 耐 & 阔 & 4 \\
\hline
\end{tabular}

即ち地域的に紐かくみる上杪北で多少早、所が あるが大部分け4月に最多であつて，火笑恔多月

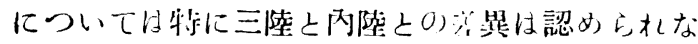
い。又掫低温度の起月沿岸上北上河谷は阴月中

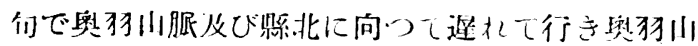

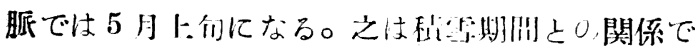

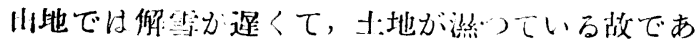
ろうが，最低温度の起日心萿異は將內で一月に滿

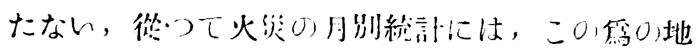

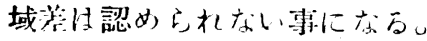

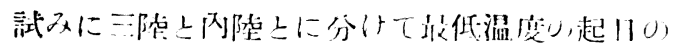

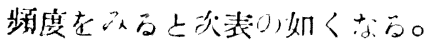

第表最肽溫度越日频度(\%)

\begin{tabular}{crrrrrrrr} 
乃 & 12 & 1 & 2 & 3 & 4 & 5 & 6 \\
\hline 三侤治崖 & 11 & 11 & 11 & 0 & 56 & 0 & 0
\end{tabular}

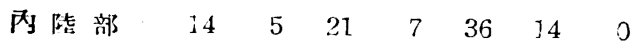

表にみる如く雨地域での售異はない。

5. 火災原匤の地理的分布 次に火绝0源因在 コタツ上か灯之か0暖居に上るもの上, 炏事上灯

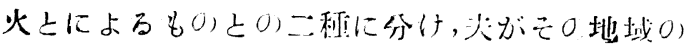

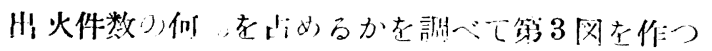

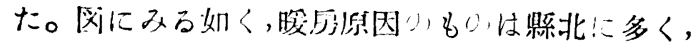
夥荫に向つて減じ，炊乎灯火在原因上するものは 跞南に多く䅫北に向つて減じる。网の上で二つの゙

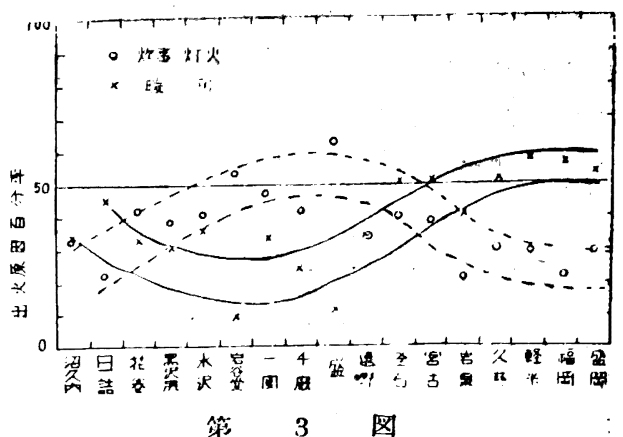

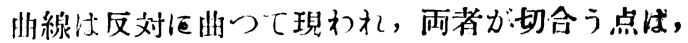
冈尖では北谷附近, 三陵沿岸では高閒附近であ る。こ0両地点在略々東西に結ぶ線が，火经原因 别に踩內在分離す万地理的境界亡なる。强いて云 へば，この線け荫側は暖地性火火煚，北側は寒地性 火災の發生する㭶所である。

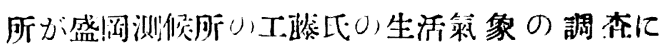
よる上, 岩手榡でュタツを使成し始め万時刀平均 乘温は $9^{\circ} \mathrm{C}$ であつて，之り頻度分布はかなりシ ヤープである。コタツを終へら洔季も矢张り $9^{\circ} \mathrm{C}$ であるが，徭者では頻度分布がかなり分散する事 が分つだ。

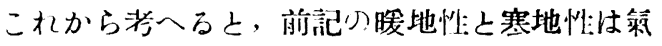
温の差であつて，4 月頃橴南では既にコタツを終 えてるるのに稲北では来だコタツが使用されてい ると云う事に原因小る0であろう。

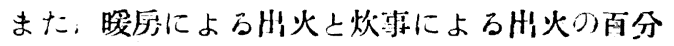

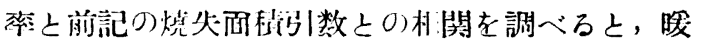
厄については, 相関係数は +0.38で多少相関が ある。即与暖原地域の方が火事が搪り易い倾向が あるが，統的には行意とは云えない程度であ 万。後者の炊事原因の方は全く相関が然い。

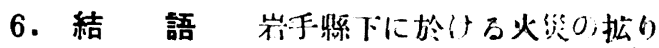

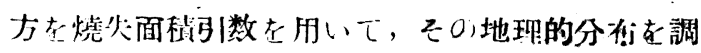

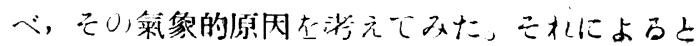

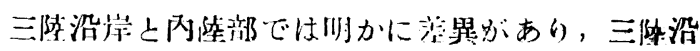

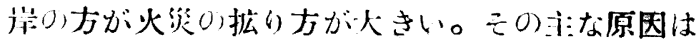
風力であると考へられる。烌々0，火贸では温度の 低い事が压倒的原因であるが，搪り方に対しては 主に風の影響が利いていてそれが地域性女示すの であ万う。又火桨原因には暖地性の炊事, 灯火上

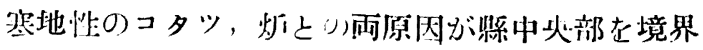
としてかなり截然と分れる。その理虫はこタツ灯 う)使用期闑に絬び一いていて，夫れは間接的に氣 温で支配されている。 